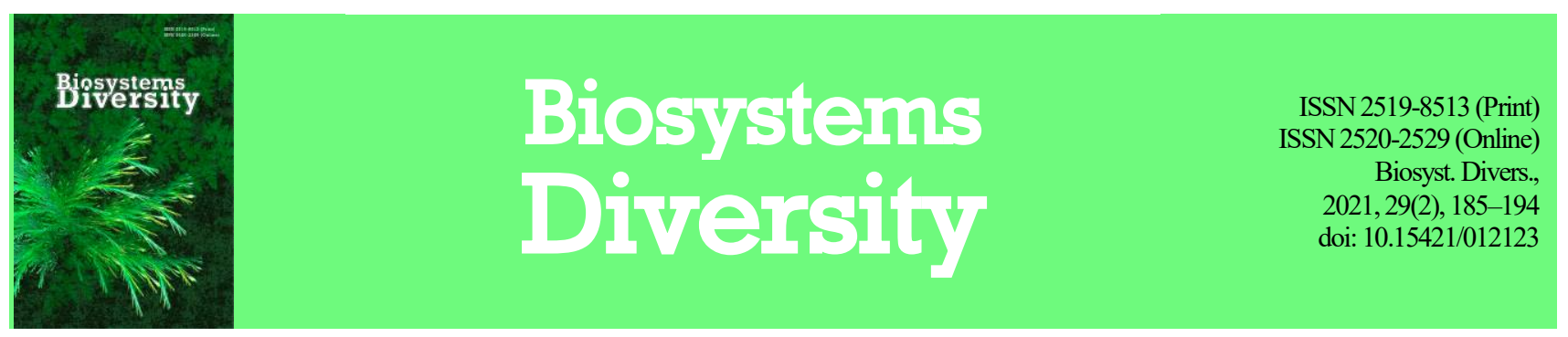

\title{
Bacillariophyta of the Yavorivsky National Park, Broadleaf Forest Zone of Ukraine, including Caloneis albus-columba, sp. nov.
}

\author{
L. N. Bukhtiyarova \\ Institute for Evolutionary Ecology, National Academy of Sciences of Ukraine, Kyiv, Ukraine
}

Article info

Received 30.04.2021

Received in revised form

23.06.2021

Accepted 24.06.2021

Institute for Evolutionary

Ecology, National

Academy of Sciences

of Ukraine,

Acad. Lebedev st. 37

Kyiv, 03143, Ukraine.

Tel.: + 38-044-526-20-51.

E-mail:

l.bukhtivarova@gmail.com

\author{
Bukhtiyarova, L. N. (2021). Bacillariophyta of the Yavorivsky National Park, Broadleaf Forest Zone of Ukraine, including Caloneis \\ albus-columba, sp. nov. Biosystems Diversity, 29(2), 185-194. doi:10.15421/012123
}

Diatoms (Bacillariophyta) are one of the major biological components in all kinds of aquatic ecosystems both in freshwater and marine ones. The nature reserve fund of Ukraine includes 52 national parks, in the vast majority of which Bacillariophyta have not been studied. This investigation presents first data on the diatoms in Yavorivsky National Park located in Lviv region. The material consists of the epiphytic samples of microalgae that were collected from different substrates in aquatic ecosystems of the Yavorivsky National Park in 2014. In the hydrotopes of the park 180 diatom species from 56 genera were found, among them Achnanthidium catenatum (Bily \& Marvan) Lange-Bertalot, Cymbopleura apiculata Krammer, Fallacia sublucidula (Hustedt) D. G. Mann in Round, Crawford \& Mann, Gomphonema lagenula Kützing, G. supersedens Reichardt, G. pseudopusillum Reichardt, Paraplaconeis minor (Grunow) LangeBertalot, Placoneis constans (Hustedt) E. J. Cox, Psammothidium bioretii (Germain) Bukhtiyarova \& Round, P. vernadskyi Bukhtiyarova et Stanislavskaya, Sellaphora gracillima Zidarova, Kopalová \& Van de Vijver, S. insolita (Manguin) Hamilton et Antoniades, Stauroneis fluminopsis Van de Vijver et Lange-Bertalot were recorded for the first time in Ukraine. Besides that, Amphora hemicycla Stoermer \& J. J. Yang and Sellaphora bacilloides (Hustedt) Levkov, Krstic \& Nakov also were new findings in the country from the Broadleaf Forest Zone of Ukraine. Many species rare in the world flora and in Ukraine were found. A new diatom species Caloneis albus-columba Bukhtiyarova, sp. nov., was described from the pond in stationary recreation area Kozulka. This new species possesses strongly threeundulate valves with three rhombic segments, which in morphology is most similar to Caloneis lamella Zakrzewski, however it differs from it by having rhombic distal valve segments instead of oval ones as well as noticeably smaller width of the central valve segment. The morphology of other similar species is discussed. For proper description of the new species new definitions for the raphe system morphology were grounded on functional morphology of the diatom frustule. New combinations Iconella alaskaensis (Foged) Bukhtiyarova, comb. et stat. nov., Iconella baltica (Schumann) Bukhtiyarova, comb. nov., Iconella brebissonii (Krammer \& Lange-Bertalot) Bukhtiyarova, comb. nov., Iconella brightwellii (W. Smith) Bukhtiyarova, comb. nov., Iconella constricta (Grunow) Bukhtiyarova, comb. et stat. nov., Iconella didyma (Kützing) Bukhtiyarova, comb. nov. and Iconella elegans (Ehrenberg) Bukhtiyarova, comb. nov. were formally proposed. The lectotype for Eunotia glacialis F. Meister was designated here. Illustrations with light and scanning electron microscopy are presented. A primary inventory of Bacillariophyta and their subsequent study on protected territories in Ukraine is still an important task in the context of preservation of biodiversity of the country.

Keywords: biodiversity; conservation; taxonomy; functional morphology; diatom frustules; new terminology.

\section{Introduction}

Diatoms are among the major biological components in aquatic ecosystems. These unicellular algae accumulate $20-25 \%$ of the world net primary production (Treguer et al., 1995) and play a significant role in biogeochemical processes (Vernadskiy, 1923; Streett-Perrott et al., 2008), in contribution to the global oxygen biosynthesis (Streett-Perrott \& Barker, 2008) and as a primary link in food chains.

The nature reserve fund of Ukraine includes 52 national parks, in the vast majority of which diatoms have not been studied. At the present time data on Bacillariophyta are published for Dermansko-Ostrozkyi National Park (Bukhtiyarova, 2017a), Desniansko-Starogutsky National Nature Park (Burova \& Zhezhera, 2013), National Nature Park "Pyriatynsky" (Kryvosheia, 2017), Nyzhniosulsky National Park (Kryvosheia \& Kapustin, 2019a, b), Pryp'yat'-Stokhid National Park (Konischuk, 2017), Shatsk National Park (Bukhtiyarova, 2007a; Krivenda, 2007, 2012; Malakhov et al., 2017).

Yavorivsky National Park is located in Yavoriv district, Lviv region (Fig. 1), total area about 7,100 ha. Its territory is a part of Ukrainian Roztochya - narrow range of hills $75 \mathrm{~km}$ long. This area has the features of three geographic regions - the Carpathians, Polissya and Podillya (Yavorivsky National Park, www.karpaty.info/en/uk/lv/jv/ivano.frankove/sights/yavorivsky.npp).
Recreation areas have been fixed and equipped here, including the Vereshchytsia River with two ponds and the Kozulka River with two reservoirs.

Systematic of Bacillariophyta and their species identification are based on morphology of the siliceous frustule - solid transperant outer shell with various structural elements that are still insufficiently studed. Functional morphology of the diatom frustule includes a number of theses. In particular, the division of all its structural elements into basic elements and functional units, can provide encouraging results in the field of studies of diatoms (Bukhtiyarova, 2009a, 2019a, b).

The basic element of the diatom frustule (db-element) is a morphologically detached, homogeneous part of the frustule that possesses special physical-chemical features and provides a primary basis for the frustule hierarchical construction. They belong to db-elements of the diatom frustule as different apertures and cavities in its thickness, regularly repeated and unique silica microelements (Bukhtiyarova, 2009a: Figs. 1-5).

Morph of the diatom frustule (df-morph) is a compound structural unit of the diatom frustule that is constructed of db-elements or structural units of lower orders, realizes particular functions in the diatom organism and has its own evolution (Bukhtiyarova, 2009a).

Recently taxonomical changes in the genera Surirella Tirpin and $C y$ matopleura W. Smith were introduced and genus Iconella Jurilj was recovered. In Iconella species the raphe channel is raised above valve 
surface and the wing channels extend from it (Ruck et al., 2016a, b; Jahn et al., 2017). Several species in the diatom flora of Ukraine are still incorrectly placed in the taxonomy.

The universal layout for the diatom species and genera description that reflects the hierarchal structure of the diatom frustule was first suggested and applied for monoraphid species and genera (Bukhtiyarova, 2007b, 2017b; Bukhtiyarova \& Stanislavskaya, 2013) and then for a number of new taxa from Lake Baikal (Bukhtiyarova \& Pomazkina, 2013) and species of the genus Eunotia Ehrenberg (Bukhtiyarova, 2019b). Some refined definitions on morphology of the raphe system of the diatom frustule that were introduced recently (Bukhtiyarova, 2019b) will be used in the present study.

The aim of this study was primary inventory of Bacillariophyta in aquatic ecosystems of the Yavorivsky National Park. New morphological structures in the raphe system in Caloneis Cleve species and correspondent terminology are suggested on the base of functional morphology.

\section{Materials and methods}

Samples of epiphytic microalgae were collected from different substrates in the aquatic ecosystems of the Yavorivsky National Park in 2014.

Organic matter was removed by cold burning with concentrated sulfuric acid and cleaned materials were rinsed several times with distilled water (Wasser et al., 1989). Permanent slides with cleaned materials were mounted in Naphrax $($ R.1 = 1.7). Diatom species were examined with light microscope (LM) Olympus BX 51 (Japan) using 100× oil immersion PlanAchromat objective. The frustules fine structure was observed with scanning electron microscope JEOL 6060LA (Japan), the Centre of Collective Use at the M. G. Kholodny Institute of Botany of the National Academy of Sciences of Ukraine. The micrographs were obtained with Canon EOS 600 D digital camera using program Helicon Remote (version 3.6.2 w).

The frequency of occurrence of the species was estimated as the number of samples in which it was found to the total number of studied samples. Species with a frequency of occurrence over $50 \%$ were attri- buted to the species complex with frequent occurrence. Species whose frequency of occureance did not exceed 1-2\% were attributed to the rare species. For valid taxa names and their distribution in the world flora a database of information on algae was used: AlgaeBase, world-wide electronic publication, National University of Ireland, Galway www.algaebase.org = (Guiry, M. D. in Guiry, M. D., \& Guiry, G. M. (2021). Morphology of Caloneis lewisii R. M. Patrick is discussed on the basis of the illustrations in: Diatoms of North America. Retrieved June 12, 2021, from https://diatoms.org/species/caloneis_lewisii = (Keith \& Rosen, 2012).

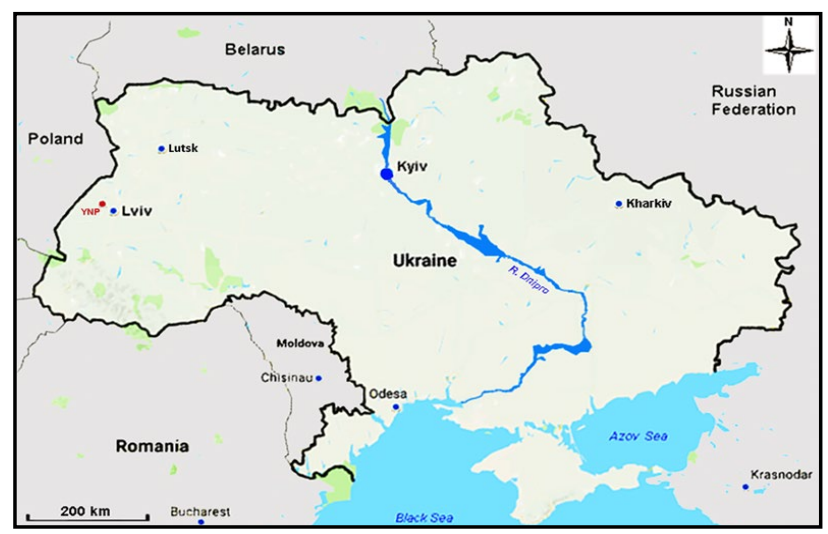

Fig. 1. Location of the Yavorivsky National Park, indicated by red dot, on the map of Ukraine

\section{Results}

Primary inventory of Bacillariophyta in the Yavorivsky National Park (YNP) resulted in recording 180 species from 56 genera (Table 1). This included numerous species rare in the world flora and in Ukraine.

Table 1

Bacillariophyta of the Yavorivsky National Park

\begin{tabular}{|c|c|c|c|}
\hline Taxon name & $\begin{array}{c}\text { Frequency } \\
\text { of occurrence }\end{array}$ & Taxon name & $\begin{array}{c}\text { Frequency } \\
\text { of occurrence }\end{array}$ \\
\hline Achnanthes adnata Bory & $\mathrm{r}$ & Halamphora oligotrafenta (Lange-Bertalot) Levkov & + \\
\hline **Achnanthidium catenatum (Bily \& Marvan) Lange-Bertalot & $\mathrm{r}$ & H. veneta (Kützing) Levkov & + \\
\hline A. minutissimum (Kützing) Czamecki & + & Hantzschia amphioxys (Ehrenberg) Grunow & + \\
\hline Amphipleura pellucida (Kützing) Kützing & + & Hippodonta capitata (Ehrenberg) Lange-Bertalot, Metzeltin et Witkowski & + \\
\hline Amphora commutata Grunow & + & H. hungarica (Grunow) Lange-Bertalot, Metzeltin et Witkowski & $\mathrm{f}$ \\
\hline A. copulata (Kützing) Schoeman et E.M.Archibald & + & Karayevia clevei (Grunow) Bukhtiyarova & $\mathrm{r}$ \\
\hline **A. hemicycla Stoermer et J.J.Yang & $\mathrm{r}$ & *K. rostrata (Hustedt) Kulikovskiy et Genkal & + \\
\hline A.ovalis (Kützing) Kützing & + & Lemnicola hungarica (Grunow) Round et Basson & + \\
\hline A. pediculus (Kützing) Grunow & + & Mastogloia braunii Grunow & $r$ \\
\hline Aneumastus stroesei (Østrup) D.G.Mann et Stickle & $\mathrm{r}$ & M. elliptica (C. Agardh) Cleve & + \\
\hline A. tusculus (Ehrenberg) D.G.Mann et Stickle & + & Meridion circulare (Greville) C. Agardh & $\mathrm{f}$ \\
\hline Anomoeoneis sphaerophora Pfitzer & $\mathrm{r}$ & Navicula capitatoradiata $\mathrm{H}$. Germain & + \\
\hline Aulacoseira ambigua (Grunow) Simonsen & + & N. cincta (Ehrenberg) Ralfs & + \\
\hline A. granulata (Ehrenberg) Simonsen & $\mathrm{f}$ & N. cryptocephala Kützing & + \\
\hline A. italica (Ehrenberg) Simonsen & + & N. cryptotenella Lange-Bertalot & + \\
\hline$\wedge^{*}$ Caloneis albus-columba Bukhtiyarova sp. nov. & $\mathrm{r}$ & N. gregaria Donkin & + \\
\hline C. amphisbaena (Bory) Cleve & $\mathrm{r}$ & N. lanceolata Ehrenberg & + \\
\hline C. bacillum (Grunow) Cleve & + & N. menisculus Schumann & + \\
\hline${ }^{*}$ C. limosa (Kützing) R.M.Patrick & $\mathrm{r}$ & $N$. radiosa Kützing & $\mathrm{f}$ \\
\hline C. molaris (Grunow) Krammer & $\mathrm{r}$ & N. reichardtiana Lange-Bertalot & + \\
\hline Cocconeis disculus (Schumann) Cleve & + & N. reinhardtii (Grunow) Grunow & + \\
\hline C. euglypta Ehrenberg & + & N. slesvicensis Grunow & + \\
\hline C. lineata Ehrenberg & + & N. tripunctata (O.F. Müller) Bory & + \\
\hline C. pediculus Ehrenberg & + & N. veneta Kützing & + \\
\hline C. placentula Ehrenberg & $\mathrm{f}$ & $N$. viridula (Kützing) Ehrenberg & $r$ \\
\hline *Craticula ambigua (Ehrenberg) D.G.Mann & $\mathrm{r}$ & Neidium ampliatum (Ehrenberg) Krammer & + \\
\hline C. buderi (Hustedt) Lange-Bertalot & + & N. dubium (Ehenberg) Cleve & $\mathrm{f}$ \\
\hline C. cuspidata (Kutzing) D.G.Mann & + & Navigeia decussis (Østrup) Bukhtiyarova & $r$ \\
\hline C. halophila (Grunow) D.G.Mann & + & Nitzschia acicularis (Kützing) W. Smith & + \\
\hline Cyclostephanos dubius (Hustedt) Round & $\mathrm{r}$ & N. dissipata (Kützing) Rabenhorst & + \\
\hline Cyclotella meneghiniana Kützing & + & N. fonticola (Grunow) Grunow & + \\
\hline Cymbella affiniformis Krammer & + & N. frustulum (Kützing) Grunow & + \\
\hline C. affinis Kützing & + & N. linearis W. Smith & + \\
\hline
\end{tabular}




\begin{tabular}{|c|c|c|c|}
\hline Taxon name & $\begin{array}{c}\text { Frequency } \\
\text { of occurrence }\end{array}$ & Taxon name & $\begin{array}{c}\text { Frequency } \\
\text { of occurrence }\end{array}$ \\
\hline C. aspera (Ehrenberg) Cleve & + & N. palea (Kützing) W. Smith & + \\
\hline C. cistula (Ehrenberg) O. Kirchner & + & N.paleacea (Grunow) Grunow & + \\
\hline C. compacta Østrup & + & **Paraplaconeis minor (Grunow) Lange-Bertalot & $r$ \\
\hline C. cymbiformis C.Agardh & + & P. placentula (Ehrenberg) Kulikovskiy et Lange-Bertalot & + \\
\hline C. helvetica Kutzing & + & Pinnularia borealis Ehrenberg & + \\
\hline C. neocistula Krammer & + & P. brebissonii (Kützing) Rabenhorst & + \\
\hline C. tumida (Brébisson) Van Heurck & $\mathrm{f}$ & P. gibba (Ehrenberg) Ehrenberg & + \\
\hline C. tumidula Grunow & + & P. interrupta W. Smith & + \\
\hline **Cymbopleura apiculata Krammer & $\mathrm{r}$ & P. macilenta Ehrenberg & + \\
\hline C. cuspidata (Kützing) Krammer & + & P. mesogongila Ehrenberg & $r$ \\
\hline C. inaequalis (Ehrenberg) Krammer & + & P. major (Kützing) Rabenhorst & + \\
\hline C. naviculiformis (Auerswald) Krammer & + & P. microstauron (Ehrenberg) Cleve & + \\
\hline C. subaequalis (Grunow) Krammer & $\mathrm{r}$ & *Placoneis abiskoensis (Hustedt) Lange-Bertalot et Metzeltin & $\mathrm{r}$ \\
\hline${ }^{*}$ C. subcuspidata (Krammer) Krammer & $\mathrm{r}$ & **P. constans (Hustedt) E. J. Cox & + \\
\hline Denticula tenuis Kützing & $\mathrm{r}$ & P. elginensis (W. Gregory) E. J. Cox & $\mathrm{r}$ \\
\hline Diatoma tenuis C. Agardh & + & P. gastrum (Ehrenberg) Mereschkowsky & + \\
\hline D. vulgaris Bory & + & P. incerta Vishnyakov & $r$ \\
\hline Diploneis oculata (Brébisson) Cleve & + & Planothidium frequentissimum (Lange-Bertalot) Lange-Bertalot & + \\
\hline D. parma Cleve & $\mathrm{r}$ & P. lanceolatum (Brébisson) Lange-Bertalot & + \\
\hline Ellerbeckia arenaria (D. Moore) Dorofeyuk et Kulikovskiy & $\mathrm{r}$ & Prestauroneis protracta (Grunow) Kulikovskiy et Glushchenko & + \\
\hline Encyonema cespitosum Kützing & + & **Psammothidium bioretii (Germain) Bukhtiyarova et Round & $\mathrm{r}$ \\
\hline E. leibleinii (C. Agardh) W. J. Silva, R. Jahn et al. & + & $\wedge * P$. vernadskyi Bukht. et Stanislavsk & $\mathrm{r}$ \\
\hline E. minutum (Hilse) D. G. Mann & + & Pseudostaurosira brevistriata (Grunow) D. M. Williams et Round & + \\
\hline E. silesiacum (Bleisch) D. G. Mann & + & Rhoicosphenia abbreviata (C. Agardh) Lange-Bertalot & $\mathrm{f}$ \\
\hline Encyonopsis cesatii (Rabenhorst) Krammer & $\mathrm{r}$ & Rhopalodia gibba (Ehrenberg) O. Müller & f \\
\hline Epithemia adnata (Kützing) Brébisson & $\mathrm{f}$ & Sellaphora americana (Ehrenberg) D. G. Mann & $\mathrm{f}$ \\
\hline E. sorex Kützing & $\mathrm{f}$ & **S. bacilloides (Hustedt) Levkov, Krstic et Nakov & + \\
\hline E. turgida (Ehrenberg) Kützing & + & S. bacillum (Ehrenberg) D. G. Mann & + \\
\hline Eunotia curtagrunowii Nörpel-Schempp et Lange-Bertalot & + & **S. gracillima Zidarova, Kopalová et Van de Vijver & $\mathrm{r}$ \\
\hline *E. glacialis F. Meister & $\mathrm{r}$ & **S. insolita (Manguin) Hamilton et Antoniades & $\mathrm{r}$ \\
\hline E. lunaris (Ehrenberg) Grunow & + & S. laevissima (Kützing) D. G. Mann & + \\
\hline E.minor (Kützing) Grunow in Van Heurck & + & S. pupula (Kützing) Mereschkovsky & $\mathrm{f}$ \\
\hline Fallacia pygmaea (Kützing) Stickle et D. G. Mann & + & Stauroneis anceps Ehrenberg & + \\
\hline **F. sublucidula (Hustedt) Mann & + & **S. fluminopsis Van de Vijver et Lange-Bertalot & $\mathrm{r}$ \\
\hline Fragilaria capucina Desmazières & + & *S. lauenburgiana Hustedt & $\mathrm{r}$ \\
\hline F. crotonensis Kitton & $\mathrm{r}$ & S. phoenicenteron (Nitzsch) Ehrenberg & + \\
\hline F. rumpens (Kützing) G. W. F. Carlson & + & S. smithii Grunow & $r$ \\
\hline F. tenera (W. Smith) Lange-Bertalot & + & Staurosira binodis (Ehrenberg) Lange-Bertalot & + \\
\hline F. vaucheriae (Kützing) J. B. Petersen & + & S. construens Ehrenberg & + \\
\hline Iconella constricta (Grunow) Bukhtiyarova, comb. et stat. nov. & $\mathrm{r}$ & Staurosirella leptostauron (Ehrenberg) D. M. Williams et Round & + \\
\hline Gomphonema acuminatum Ehrenberg & + & Stephanodiscus hantzschii Grunow & $\mathrm{f}$ \\
\hline${ }^{*}$ G. angusticephalum Reichardt et Lange-Bertalot & $\mathrm{r}$ & S. neoastrea Håkansson et Hickel & + \\
\hline G. augur Ehrenberg & + & Surirella angusta Kützing & + \\
\hline G. brebissonii Kützing & $\mathrm{r}$ & I. brebissonii (Krammer \& Lange-Bertalot) Bukhtiyarova, comb. nov. & + \\
\hline G. capitatum Ehrenberg & + & S. hibernica (W. Smith) Kapustin et Kryvosheya & $r$ \\
\hline G. coronatum Ehrenberg & + & S. librile (Ehrenberg) Ehrenberg & + \\
\hline G. gautieri (Van Heurck) Lange-Bertalot et Metzeltin & $\mathrm{r}$ & Tabellaria flocculosa (Roth) Kützing & $\mathrm{f}$ \\
\hline G. gracile Ehrenberg & + & Tryblionella angustata W.Smith & + \\
\hline G. italicum Kützing & + & T. angustata var. acuta (Grunow) Bukhtiyarova & + \\
\hline$\wedge^{\wedge} G$. lagenula Kützing & $\mathrm{r}$ & T. gracilis W. Smith & $r$ \\
\hline G. minutum (C. Agardh) C. Agardh & + & T. levidensis W. Smith & + \\
\hline G. parvulum (Kützing) Kützing & + & T. hungarica (Grunow) Frenguelli & + \\
\hline G. pseudoaugur Lange-Bertalot & + & Ulnaria acus (Kützing) Aboal & + \\
\hline$\wedge * G$. supersedens Reichardt & $\mathrm{r}$ & U. amphirhynhus (Ehrenberg) Compère et Bukhtiyarova & + \\
\hline${ }^{\wedge} G$. pseudopusillum Reichardt & $\mathrm{r}$ & U. biceps (Kützing) Compère & $r$ \\
\hline G. subclavatum (Grunow) Grunow & + & U. capitata (Ehrenberg) Compère & + \\
\hline G. truncatum Ehrenberg & + & U. danica (Kützing) Compère et Bukhtiyarova & + \\
\hline Gyrosigma acuminatum (Kützing) Rabenhorst & + & U. ulna (Nitzsch) Compère & + \\
\hline
\end{tabular}

Notes: ${ }^{* *}$ - species recorded for the first time in Ukraine, ${ }^{\wedge}$ - rare species in the world flora that are recorded for the first time in Ukraine; ${ }^{*}$-rare species in Ukraine; frequency of occurrence: $\mathrm{f}-$ over $50 \%, \mathrm{r}-$ not exceed $1-2 \%,+-$ was not calculated.

Species that occurred most frequently in the studied water ecosystems were Stephanosiscus hantzschii, Aulacoseira gramulata, Tabellaria flocculosa, Meridion circulare, Navicula radiosa, Neidium dubium, Cymbella tumida, Lemnicola hungarica, Cocconeis placentula, Sellaphora americana, S. pupula, Rhoicosphenia abbreviata, Rhopalodia gibba, Epithemia adnata and $E$. sorex. A large proportion of the species occurred very rarely, actually, as single specimens in one sample, which gives evidence about their low populations and the threat to their survival even in protected areas.

To describe the new species, it was necessary to introduce new morphological structures of the diatom frustule. The new definitions suggested here are based on the functional morphology of the diatom frustue.

Raphe lamina (r-lamina) - micro- db-element in the form of narrow thin long hyaline plate which ranges along one of the raphe edge and covered part or whole raphe slit together with central raphe pores on inner valve surface. Lamina restricts contact of the protoplast with the environment through the raphe (Fig. 9a, arrows).

The raphe lamina in some species of the genus Caloneis is so thin that central raphe pores on the outer valve surface are shone through from the inner valve surface, which allowed us to discover this db-element. Morphology of raphe lamina in Caloneis has species rank of taxonomy.

Raphe lamina alas (rl-alas) - proximal raphe lamina parts which covered central raphe pores and proximal parts of the raphe slits (Fig. 9a, double arrows).

In small species rl-alas may absent, for instance, in Caloneis fontinalis (Grunow) Lange-Bertalot et Reichardt (see Van de Vijver et al., 2020: Fig. 53). 

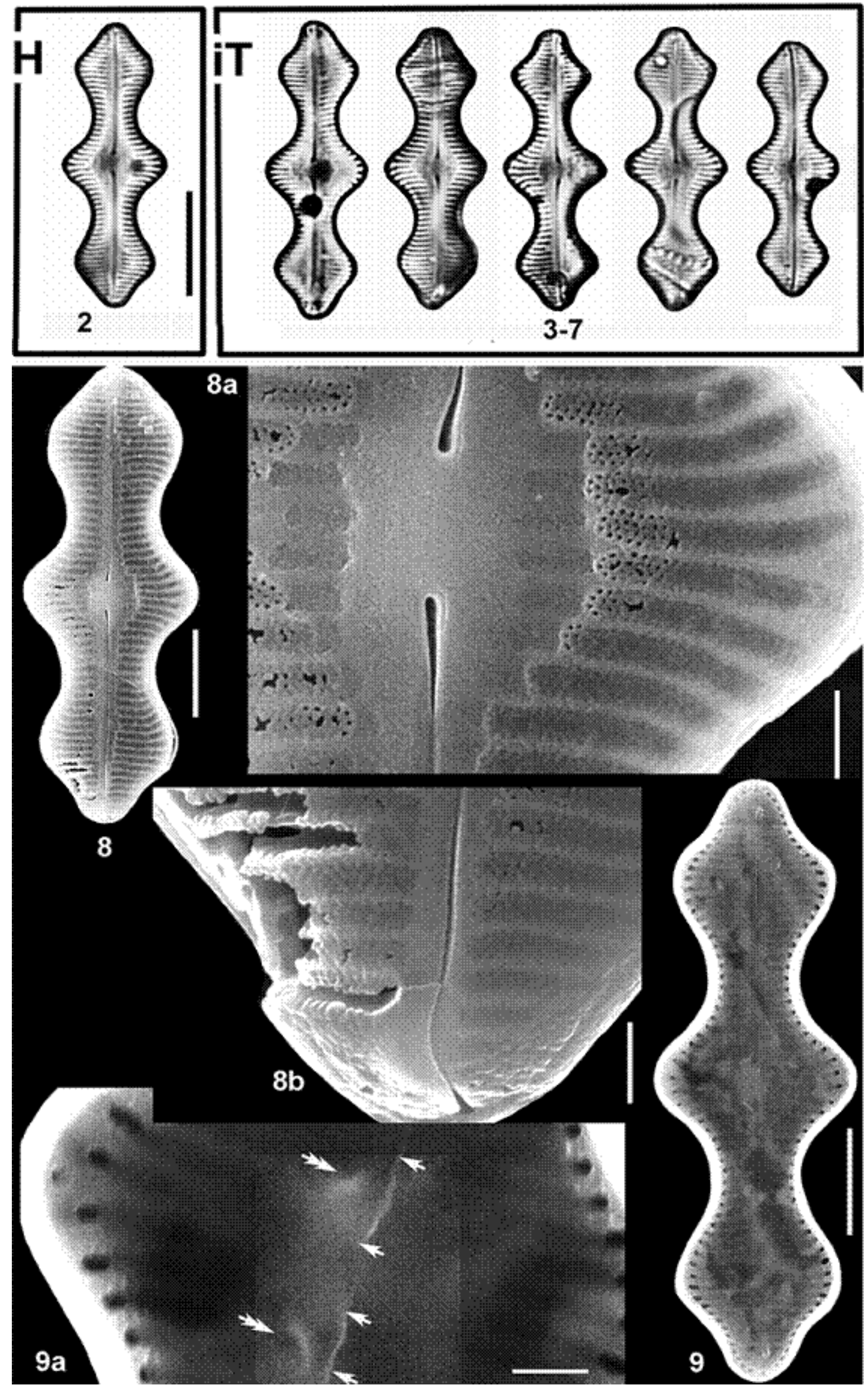

Figs. 2-9. Caloneis albus-columba Bukhtiyarova, sp. nov., from the Yavorivsky National Park, Ukraine: 2 - Holotype; 3-7-Isotypes, designated here; $8-8 b$ - outer valve surface; $8 a-$ fragment of central valve part with widened central raphe pores turned to one side; $8 b-$ valve pole with terminal raphe fissures; 9, 9a-inner valve surface; $9 a$ - fragment of central valve part; (2-7) - light microscopy; (8-9a) - scaning electron microscopy; scale bars $-10 \mu \mathrm{m}(2-7), 5 \mu \mathrm{m}(8,9), 1 \mu \mathrm{m}(8 a, b, 9 a)$ 
Caloneis albus-columba Bukhtiyarova, sp. nov. (Figs. 2-7 LM, 8-9a SEM)

Holotype: Fig. 2

Isotypes: Figs. 3-7, designated here.

Description. Morphometric data: length 26-28 $\mu \mathrm{m}$; width centre 99.5 , midlle 3-4, poles 7.0-7.5 $\mu \mathrm{m}$; striae density $20-24$ in $10 \mu \mathrm{m}$.

Frustule three-symmetric, bi- and isopolar, biraphid with mirrorsymmetric raphe system. Valves strongly three-undulate with three rhombic segments and sometimes slightly rostrate poles (Figs. 2-7). Axial area very narrow, central area rhombic, occupies 0.5 of valve width (Fig. 8a). Striae alveolate with oval alveola openings along valve mantle, multiseriate - 4-rows, compacted, at the right angle to the axial valve axis, at central segment can be arch-like (Figs. 8, 8a). Areolae with small round outer foramens. Raphe system mirror-symmetric; on the outer valve surface central raphe pores are long wide, slightly turned to the same side, on the inner surface, they are closed by raphe lamina; terminal raphe fissures have a long hook-like finish on the valve mantle (Fig. 9b).

Diagnosis. Morphology of the new species is most similar to Caloneis lamella Zakrzewski (1934: Fig. 4), which was described from Lake Balkhash but differs from it by having rhombic distal valve segments vs oval ones as well as by the noticeably smaller width of the central segment (9.0-9.5 $\mu \mathrm{m}$ vs $15 \mu \mathrm{m})$ having comparable valve length $(26-28 \mu \mathrm{m}$ vs $35 \mu \mathrm{m})$. The valve outline is the main difference between both species.

Type information. Locality and hydrotope: Ukraine, Lvivska region, Yavorivsky district, Yavorivsky Natonal Park, stationary recreation area Kozulka, Lake N 2, epiphyton on dead Typha sp. Coordinates: $50^{\circ} 04^{\prime} 20.6^{\prime \prime} \mathrm{N} 23^{\circ} 77^{\prime} 92.8^{\prime \prime}$ E. Materials: slide N 14-77 with the Holotype and Isotype specimens, sample N 14-77 in Collection of L. Bukhtiyarova, Kyiv, Institute for Evolutionary Ecology of the National Academy of Sciences of Ukraine.

Etymology. The specific epithet, the noun albus-columba, is derived to commemorate the memory of Dmitriy Maksimov, Hero of Ukraine, bronze and silver prize-winner of Deaf-Olympic Games in Judo. During the Revolution of Dignity 2014, Dmitriy spent many nights guarding the barricades on Maydan in Kyiv city centre and holding back attacks by the security forces. On 18 February 2014, Dmitriy jumped to cover with his own body a grenade that was thrown at the people. He perished, saving the people around him. When his friend came afterwards to that place to remember Dmitriy, a white dove sat on the Maydan asphalt. When that same friend came there with Dmitriy's mother, a white dove again sat on the asphalt.

Illustrations. As Caloneis lamella Zakrzewski: Krammer et LangeBertalot 1986: Pl. 171/Fig. 4; Rumrich et al. 2000: Pl. 135/Fig. 5.

Ecology. Freshwater epiphytic species.

Distribution. Europe: Type locality - Ukraine, Lvivska region, Yavorivsky Natonal Park. North America: USA (Krammer \& Lange-Bertalot 1986, as Caloneis lamella). South America: Venezuela (Rumrich et al. 2000, as Caloneis lamella). In Ukraine. Type locality.

Three taxa comparable in valve outline with Caloneis albus-columba, sp. nov., were typified based on the original illustrations by the authors of those taxa. Every taxon was represented with single illustration, which in such case is a holotype even the author did not choose it in a protolog (Turland et al., 2018 (Art. 9.1); Turland, 2019).

Caloneis lamella Zakrzewski, 1934: Fig. 4 (= Holotype).

Navicula trinodis var. inflata Schultze, 1889: Pl. 90/Fig. 7(=Holotype).

Caloneis lewisii R. M. Patrick, 1945: Pl. 2/Fig. 4 (= Holotype).

Distribution of every species below was checked using AlgaeBase (Guiry M.D. in Guiry \& Guiry 2021), however the references with different kind of compilations or checklists that are not new records in fact were not taken into account or were included one time for the same country.

Achnanthidium catenatum (Bily et Marvan) Lange-Bertalot in Lange-Bertalot et Genkal, 1999: p. 271. (Figs. 28-30)**

Morphometric data: length 9-15 $\mu \mathrm{m}$; width $3 \mu \mathrm{m}$, striae density 28 30 in $10 \mu \mathrm{m}$.

Distribution. Europe: Type locality - Czech Republic, R. Zelivka, Sedlice Reservoir. Albania, France, Germany, the Netherlands, North Macedonia, Slovakia, Romania, Scandinavia. Asia: China, Korea. North America: Mexico. South America: Argentina, Colombia (Guiry M. D. in Guiry \& Guiry, 2021). In Ukraine. YNP, Fiina village, River Fïna near old mill, fishery "Mlynky", sporty pond N4.
Amphora hemicycla Stoermer et J. J. Yang, 1971: p. 402, Figs. 5a-c (Fig. 10) $)^{\wedge *}$

Morphometric data: length 50-60 $\mu \mathrm{m}$; width 12-15 $\mu \mathrm{m}$, striae density $11-12$ in $10 \mu \mathrm{m}$.

Distribution. Europe: Germany. North America: USA. Asia: Russia (Gury M. D. in Guiry \& Guiry, 2021). In Ukraine. Rivne region, Dubna district, between the villages Bushcha and Sosnivka, River Zamyshivka.

Craticula ambigua (Ehrenberg) D. G. Mann in Round, Crawford \& Mann, 1990: p. 666. (Fig. 34)*

Morphometric data: length $62 \mu \mathrm{m}$; width $20 \mu \mathrm{m}$, striae density 14 in $10 \mu \mathrm{m}$.

Distribution. Species is widely distributed in fresh waters (Guiry M. D. in Guiry \& Guiry, 2021). In Ukraine. Kiev Upland Region (Berezovskaya, 2019), Nyzhniosulsky National Nature Park (Kryvosheia \& Kapustin, 2019); YNP, Fishery “Maydan”, pond N2.

Cymbopleura anglica (Lagerstedt) Krammer, 2003: p. 10, Pl. 4/Figs. 112, Pl. 5/Figs. 1-11, Pl. 6/Figs. 1-4,Pl. 7/Figs. 1-6, Pl. 8/Figs. 1-9. (Fig. 33)* $10 \mu \mathrm{m}$

Morphometric data: length $62 \mu \mathrm{m}$; width $20 \mu \mathrm{m}$, striae density 9 in

Distribution. Arctic. Europe: Bulgaria, France, Germany, the Netherlands, North Macedonia, Romania. Asia: China, Korea, Mongolia, Russia, Tajikistan. North America: Canada, USA. South America: Brasil (Guiry M. D. in Guiry \& Guiry, 2021). In Ukraine. Nyzhniosulsky National Nature Park (Kryvosheia \& Kapustin, 2019); YNP, Fishery "Maydan", pond N2.

Cymbopleura apiculata Krammer, 2003: pp. 12, 152, Pl. 7/Figs. 8 10, Pl. 9: Figs. 1-6, Pl. 10/Figs. 1-4, Pl. 11/Figs. 1-3 b. (Fig. 22)^*

Morphometric data: length $66 \mu \mathrm{m}$; width $23 \mu \mathrm{m}$, striae density 9-10 in $10 \mu \mathrm{m}$

Distribution. Europe: Finland, France, Germany, Romania. Asia: China, Japan, Mongolia, Russia. North America: Canada, USA. Australia: Tasmania (Guiry M. D. in Guiry \& Guiry, 2021). In Ukraine. YNP, Fishery "Maydan", wintering pond N1.

Eunotia glacialis F. Meister, 1912: pp. 85, 234, Pl. 10/Figs. 2, 3. (Figs. 26, 27)*

Lectotype: F. Meister, 1912: Pl. 10/Fig. 3, designated here. $10 \mu \mathrm{m}$.

Morphometric data: length $97 \mu \mathrm{m}$; width $6 \mu \mathrm{m}$, striae density 10 in

Distribution. Widely distributed species (Guiry M. D. in Guiry \& Guiry, 2021). In Ukraine. YNP, Fishery “Maydan”, pond N2.

Fallacia sublucidula (Hustedt) D. G. Mann in Round, Crawford \& Mann 1990: p. 669 (Figs. 12, 13)^*

Morphometric data: length 15-25 $\mu \mathrm{m}$; width 5-6 $\mu \mathrm{m}$, striae density 30 in $10 \mu \mathrm{m}$.

Distribution. Europe: Britain, France, Germany, the Netherlands, North Macedonia, Poland, Romania, Serbia. North America: USA. (Guiry M. D. in Guiry \& Guiry, 2021). In Ukraine. YNP, Fiina village, River Fiina near old mill, fishery "Mlynky", sporty pond N2.

Gomphonema lagenula Kützing 1844: p. 85, Pl. 30/Fig. 60. (Fig. 24) ** Morphometric data: length $25 \mu \mathrm{m}$; width $5 \mu \mathrm{m}$, striae density $12-14$ in $10 \mu \mathrm{m}$.

Distribution. Europe: France, Ireland, Germany, the Netherlands, North Macedonia, Serbia, Slovakia. North America: Mexico, USA. South America: Brasil, Colombia, Ecuador, Uruguay. Africa: Côte d'Ivoire, Democratic Republic of Congo, Gambia, Ghana. Asia: China, Korea, India, Iraq, Myanmar, Japan, Russia, Tajikistan, Thailand. Australia: Australia, New Zealand (Guiry M. D. in Guiry \& Guiry, 2021). In Ukraine. YNP, Fishery "Maydan", wintering pond N1; YNP, Fiina village, River Fïna near old mill, fishery "Mlynky", sporty pond N4.

Gomphonema pseudopusillum Reichardt, 1999: p. 48, Pl. 59/Figs. 115 (Fig. 21)^** $10 \mu \mathrm{m}$.

Morphometric data: length $57 \mu \mathrm{m}$; width $8 \mu \mathrm{m}$, striae density 12 in

Distribution. North America: Type locality - USA, Manzanita Lake, Lassen Volcanic National Park, California. Asia: China, Mongolia, Russia (Lake Baikal, Far East) (Guiry M.D. in Guiry \& Guiry, 2021). Europe: In Ukraine. YNP, Fishery "Maydan", pond N2.

Comment. In Europe this species rare in the world flora was recorded for the first time. 

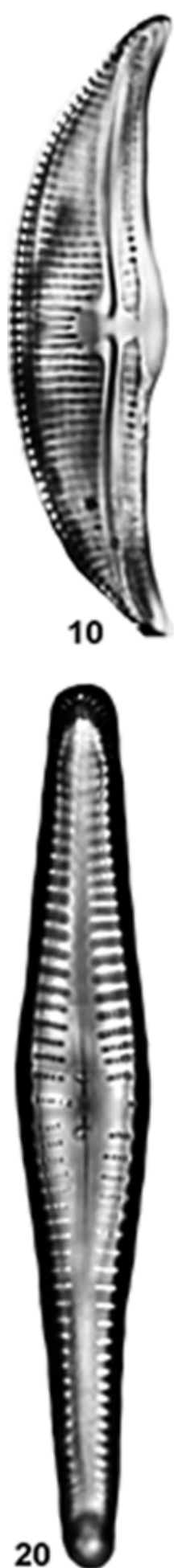

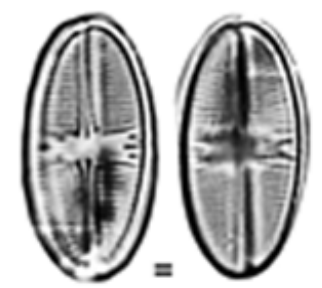

11, 11a

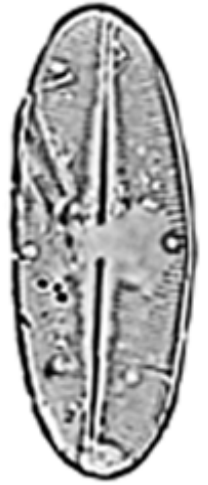

15

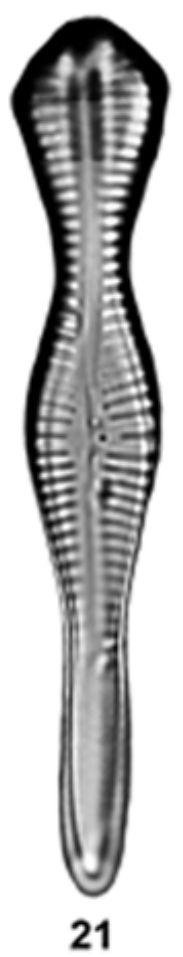

21

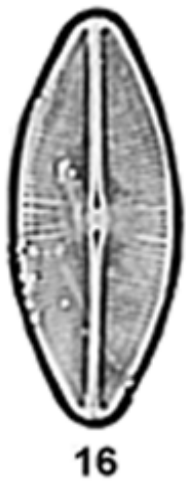

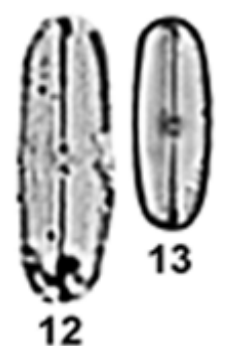

12

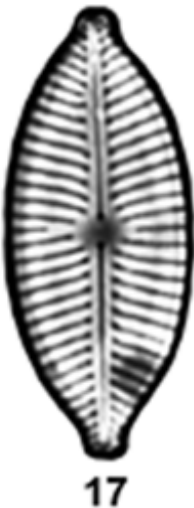

17
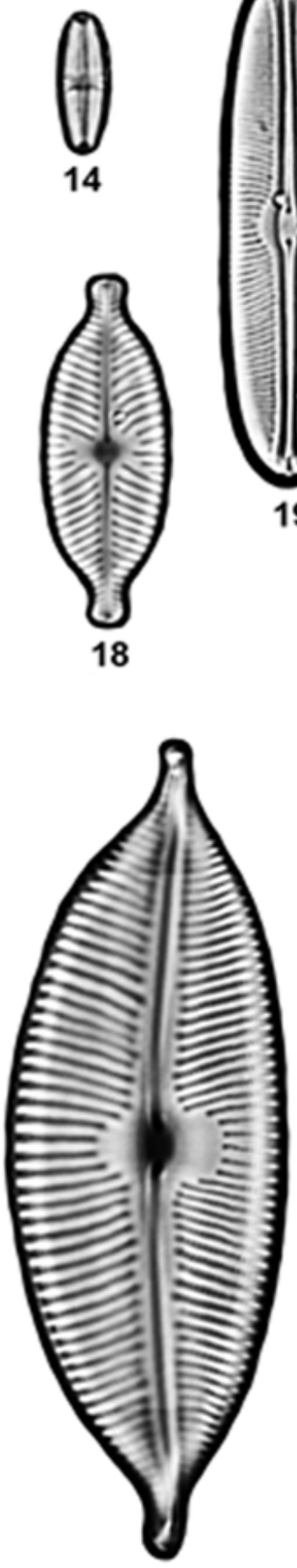

23
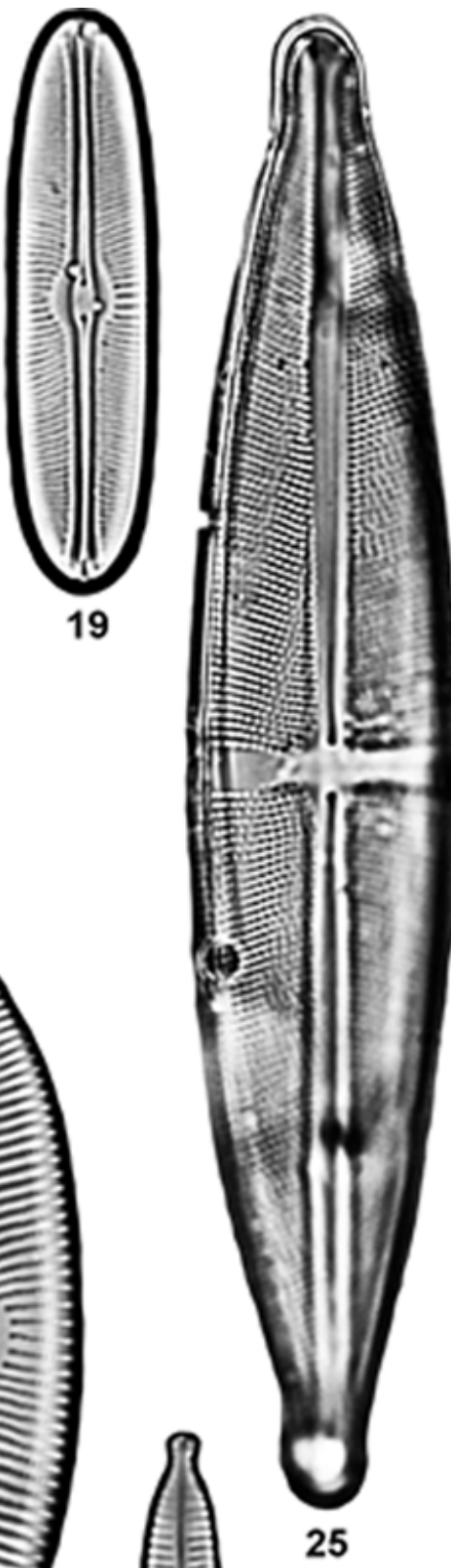

22

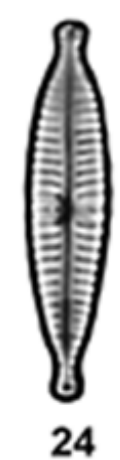

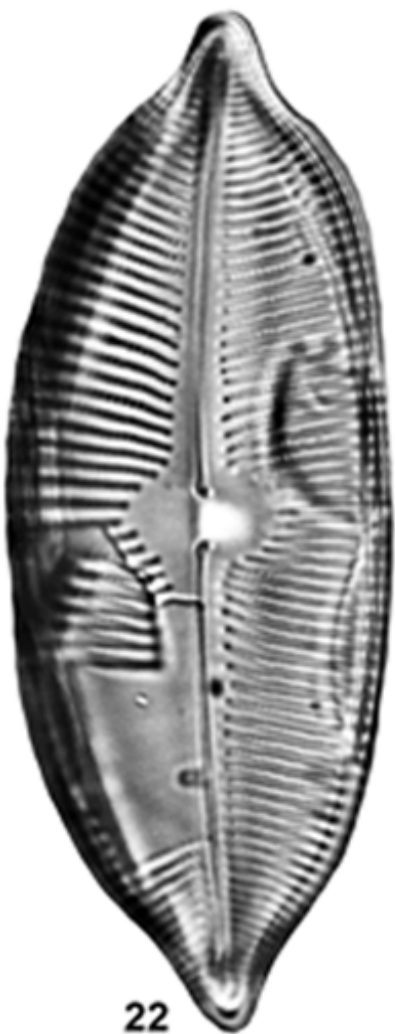

Figs. 10-25. Species of Bacillariophyta that were found for the first time in Ukraine in the Yavorivsky National Park and other locations in the Broadleaf Forest Zone: 10 - Amphora hemicycla Stoermer \& J. J.Yang; 11, 11 - Psammothidium bioretii (H. Germain) Bukhtiyarova \& Round; 12, 13 - Fallacia sublucidula (Hustedt) D. G. Mann; 14 - Sellaphora gracillima Zidarova, Kopalová \& Van de Vijver; 15 - Psammothidium vernadskyi Bukhtiyarova \& Stanislavskaya; 16-Sellaphora bacilloides (Hustedt) Levkov, Krstic \& Nakov; 17 - Paraplaconeis minor (Grunow) Lange-Bertalot; 18 -Placoneis constans (Hustedt) E. J. Cox; 19 -Sellaphora insolita (É. Manguin ex Kociolek \& B. de Reviers) Hamilton \& Antoniades; 20 - Gomphonema supersedens Reichardt; 21 - Gomphonema pseudopusillum Reichardt; 22 - Cymbopleura apiculata Krammer; 23 - Cymbopleura sp.; 24 - Gomphonema lagenula Kützing; 25 - Stauroneis fluminopsis Van de Vijver \& Lange-Bertalot; (10-25) - light microscopy; scale bar - $10 \mu \mathrm{m}$

Gomphonema supersedens Reichardt, 1999: pp. 54-55, Pl. 65/Figs. $1-9$ (Fig. 20)^*

Morphometric data: length $73 \mu \mathrm{m}$; width $10 \mu \mathrm{m}$, striae density 8 in $10 \mu \mathrm{m}$, areolae 18 in $10 \mu \mathrm{m}$.

Distribution. Europe: Type locality - Czech Republic, near Kundratice. In Ukraine. YNP, stationary recreation area N3, pond.
Karayevia rostrata (Hustedt) Kulikovskiy et Genkal in Kulikovskiy, Genkal \& Mikheyeva, 2013 (Figs. 31, 32, 32a)*

Morphometric data: length 18-20 $\mu \mathrm{m}$; width 7-8 $\mu \mathrm{m}$, striae density $16-19$ in $10 \mu \mathrm{m}$.

Distribution. Widely distributed species (Guiry M. D. in Guiry \& Guiry, 2021). In Ukraine. YNP, Fishery “Maydan”, wintering pond N3. 


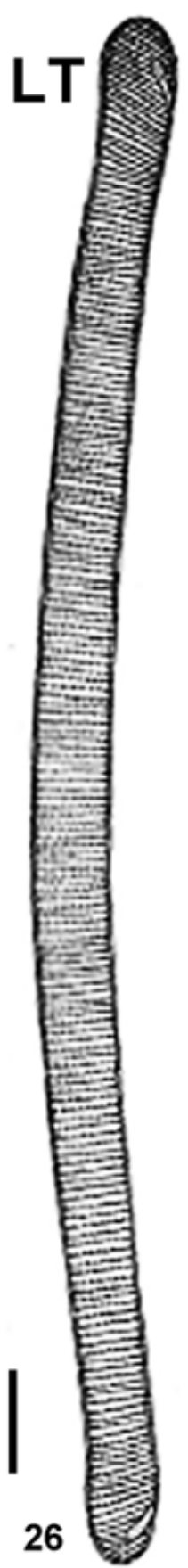

3

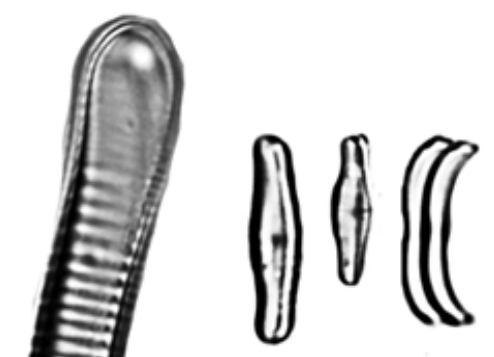

28-30

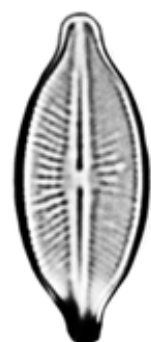

31

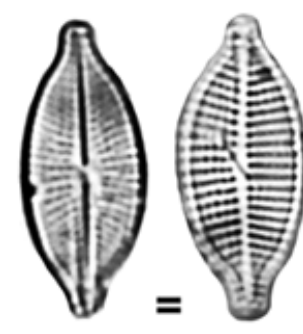

$32-32 a$
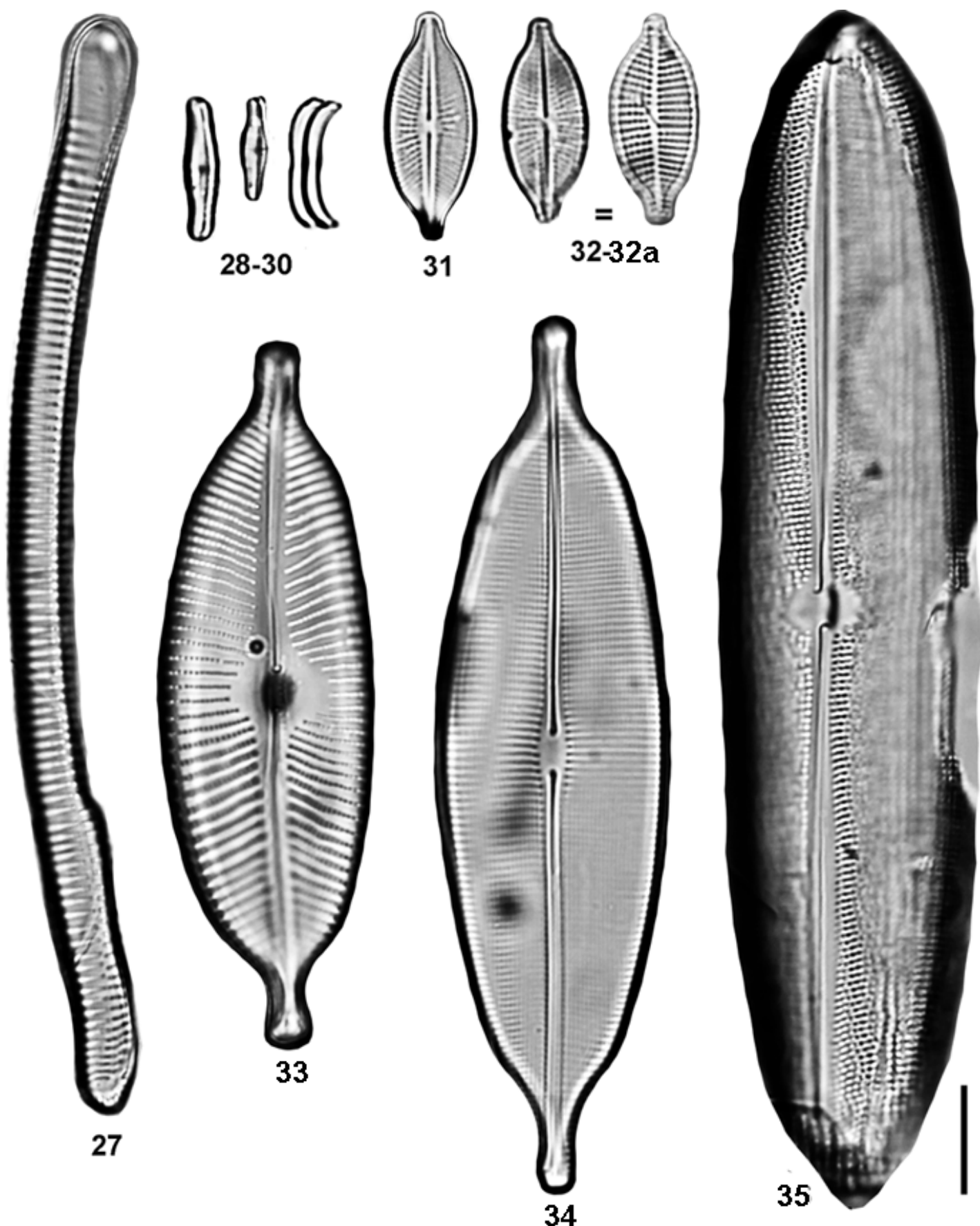

Figs. 26-35. Newly recorded and rare in Ukraine species of Bacillariophyta from the Yavorivsky National Park: 26,27-Eunotia glacialis F. Meister, 26-Lectotype of Eunotia glacialis F. Meister, 1912: Pl. 10/Fig. 3, designated here; 28-30-Achnanthidium catenatum (Bily \& Marvan) Lange-Bertalot; 31-32, 32a - Karayevia rostrata (Hustedt) Kulikovskiy \& Genkal; 33 - Cymbopleura anglica (Lagerstedt) Krammer; 34 - Craticula ambigua (Ehrenberg) D. G. Mann; 35 - Neidium sp.; scale bars - 10 $\mu$; ; (26-35) - light microscopy; Figs. 31-39=10 $\mu \mathrm{m}$

Neidium sp. (Fig. 35).

Morphometric data: length $110 \mu \mathrm{m}$; width $22 \mu \mathrm{m}$, striae density 16 in $10 \mu \mathrm{m}$.

Distribution. Ukraine, YNP, Fishery "Maydan", pond N3.

Paraplaconeis minor (Grunow) Lange-Bertalot in Lange-Bertalot et al., 2017:p. 471, Pl. 47/Figs. 47-51 (Fig. 17) ${ }^{\wedge *}$ $10 \mu \mathrm{m}$.

Morphometric data: length $29 \mu \mathrm{m}$; width $12 \mu \mathrm{m}$, striae density 11 in

Distribution. Europe: Germany, the Netherlands, North Macedonia, Poland (Guiry M. D. in Guiry \& Guiry, 2021). In Ukraine. YNP, Fishery "Maydan", wintering pond N1.

Comment. Rare in the world flora species, probably European endemic.
Placoneis constans (Hustedt) E. J. Cox, 2003: p. 73. (Fig. 18)^*

Morphometric data: length $27 \mu \mathrm{m}$; width $10 \mu \mathrm{m}$, striae density 13 in $10 \mu \mathrm{m}$

Distribution. Europe: Britain, Czech Republic, France, Germany, the Netherlands, North Macedonia, Romania. North America: USA. South America: Brazil Asia: India, Iraq, Russia, Thailand, Colombia. Australia (Guiry M. D. in Guiry \& Guiry, 2021). In Ukraine. YNP, Fishery "Maydan", wintering pond N1.

Psammothidium bioretii (Germain) Bukhtiyarova et Round, 1996: p. 9, Figs. 26-31 (Figs. 11, 11a)**

Morphometric data: length 14-17 $\mu \mathrm{m}$, width 7-8 $\mu \mathrm{m}$, striae density 28 in $10 \mu \mathrm{m}$. 
Distribution. Arctic: Canada. Europe: Britain, Bulgaria, Czech Republic, France, Germany, the Netherlands, Poland, Romania, Russia, Serbia. North America: Canada, USA (Alaska, Laurentian Great Lakes). Asia: Korea, Mongolia, Russia (Bering Island, Far East, Sakha). Pacific islands: Hawaiian Islands. Atlantic islands: Azores (Guiry M. D. in Guiry \& Guiry, 2021). In Ukraine. YNP, stationary recreation area, pond N4.

Psammothidium vernadskyi Bukhtiyarova et Stanislavskaya, 2013: p. 97, Figs. 1, 1a-7b (Fig. 15) ${ }^{\wedge *}$ $10 \mu \mathrm{m}$.

Morphometric data: length $30 \mu \mathrm{m}$; width $11 \mu \mathrm{m}$, striae density 26 in

Distribution. Asia: Type locality - Russia, East Siberia, Khanty-Mansiyskiy region, $70 \mathrm{~km}$ south-east of city Hanty-Mansiysk, Blue Lake N 29. Europe: Ukraine, YNP, stationary recreation area, pond N3.

Comment. This is second finding of this species after its description and first record in Europe.

Sellaphora gracillima Zidarova, Kopalová et Van de Vijver, 2016: p. 51, Figs. $157-177$ (Fig. 14) ${ }^{\wedge *}$ $10 \mu \mathrm{m}$.

Morphometric data: length $10 \mu \mathrm{m}$; width $3.5 \mu \mathrm{m}$, striae density 30 in

Distribution. Antarctic: Type locality - Antarctica, South Shetland Islands, Livingston Island, Byers Peninsula; Antarctic islands (Guiry M. D. in Guiry \& Guiry, 2021). Europe: In Ukraine. YNP, Fishery "Maydan", pond N5.

Sellaphora insolita (Manguin ex Kociolek et Reviers) Hamilton et Antoniades in Antoniades et al., 2008: 279 (Fig. 19) ${ }^{\wedge *}$

Morphometric data: length 40-46 $\mu \mathrm{m}$; width 9-10 $\mu \mathrm{m}$, striae density c15-16p22 in $10 \mu \mathrm{m}$.

Distribution. North America: Type locality - USA, Alaska, Lake Karluk. Asia: Russia. (Guiry M.D. in Guiry \& Guiry, 2021). Europe: Ukraine, YNP, Fïna village, River Fïna near old mill, fishery "Mlynky", pond N5.

Stauroneis fluminopsis Van de Vijver et Lange-Bertalot in Van de Vijver, Beyens \& Lange-Bertalot, 2004: p. 34, Pl. 8/Figs. 1-16; Pl. 9/Figs. 1-7 (Fig. 25)^* $10 \mu \mathrm{m}$

Morphometric data: length $100 \mu \mathrm{m}$, width $18 \mu \mathrm{m}$, striae density 18 in

Distribution. Subantarctic Islands: Type location: Prince Edward Islands. North America: USA (Guiry M. D. in Guiry \& Guiry, 2021). Europe: Ukraine, YNP, village Seredniy Horb, pond.

The following diatom species most of which were recorded in the flora of Ukraine under the names that do not correspond current taxonomy were transferred to the genus Iconella.

Iconella alaskaensis (Foged) Bukhtiyarova, comb. et stat. nov.

Basionym: Surirella amphioxys var. alaskaensis Foged, 1981. Diatoms in Alaska. Bibliotheca Phycologica 53: 164, Pl. 62/Fig. 6.

Iconella baltica (Schumann) Bukhtiyarova, comb. nov.

Basionym: Surirella baltica Schumann, 1867. Preussische Diatomeen. Schriften der koniglichen physikalisch-okonomischen Gesellschaft zu Konigsberg, 8: p. 52, Pl. 1/Fig. 7.

Synonym: Surirella brightwellii var. baltica (Schumann) Krammer.

Iconella brebissonii (Krammer \& Lange-Bertalot) Bukhtiyarova, comb. nov.

Basionym: Surirella brebissonii Krammer \& Lange-Bertalot, 1987. Morphology and taxonomy of Surirella ovalis and related taxa. Diatom Research, 2(1): pp. 82, 85, Figs. 21-26.

Comment. In the primary description the authors represented 33 illustrations of S. brebissonii among them Figs. 21-26 (LM) indicated as the Holotype from slide P 11007A in Coll. Krammer.

Iconella brightwellii (W. Smith) Bukhtiyarova, comb. nov.

Basionym: Surirella brightwellii W. Smith, 1853. A synopsis of the British Diatomaceae with remarks on their structure, function and distribution; and instructions for collecting and preserving specimens. Vol. 1: p. 33, Pl. 9/Fig. 69.

Iconella constricta (Grunow) Bukhtiyarova, comb. et stat. nov.

Basionym: Surirella linearis var. constricta Grunow, 1862. Die Österreichischen Diatomaceen nebst Anschluss einiger neuen Arten von andern Lokalitäten und einer kritischen Uebersicht der bisher bekannten Gattungen und Arten. Verhandlungen der kaiserlich-königlichen zoologischbotanischen Gesellschaft in Wien. 12: p. 455.
Synonym: Surirella grunowii Kulikovskiy et al. in Kulikovskiy et al., 2010: p. 64

non Surirella constricta W. Smith 1853: p. 31, Pl. 8/Fig. 59.

Iconella didyma (Kützing) Bukhtiyarova, comb. nov.

Basionym: Surirella didyma Kützing, 1844. Die Kieselschaligen Bacillarien oder Diatomeen. Nordhausen: p. 60, Pl. 3/Fig. LXVII [67].

Iconella elegans (Ehrenberg) Bukhtiyarova, comb. nov.

Basionym: Surirella elegans Ehrenberg, 1843. Verbreitung und Einfluss des mikroskopischen Lebens in Süd- und Nord-Amerika. Abhandlungen der Königlichen Akademie der Wissenschaften zu Berlin (1841): p. 424, Pl. 3/Fig. I.22.

\section{Discussion}

The specimen of Caloneis lewisii var. inflata (Schultze) Patrick in Patrick \& Reimer (1966: Pl. 54/Fig. 12) has similar valve outline, except rostrated poles, and striae arrangement compared with Caloneis albuscolumba, sp. nov. but larger size: length $42 \mu \mathrm{m}$; width c13, m4, p10 $\mu \mathrm{m}$; striae density 21 in $10 \mu \mathrm{m}$ (my measurements). However, this specimen differs significantly from the valve outline and type of striae in Navicula trinodis var. inflata Schultze (1889: p. 101, Pl. 90/Fig. 7) which served as a basionym for nomenclature combination. In later taxon description Schultze (1889: p. 101) underlined that it has "linear-punctate" striae that is rather similar to the species Stauroneis Ehrenberg than Caloneis. Thus, the specimen of Caloneis lewisii var. inflata sensu auct. nom., could be the one which belongs to Caloneis albulus-columba but certainly does not belong to $N$. trinodis var. inflata.

The illustrations of Caloneis lewisii R. M. Patrick (1945: p. 172, Pl. 2/Fig. 4) that are presented from population in Lakeside Lab, Pipestone National Park (Keith \& Rosen, 2012: 5 specimens) show that during vegetative reproduction frustules reduce proportionally except the smallest specimenr. These specimens (Figs. 3-5) if they are in length $35 \mu \mathrm{m}$ are conspecific with the holotype of Caloneis lamella except being less wide (12 $\mu \mathrm{m}$ vs $15 \mu \mathrm{m})$. Therefore, the opinion is supported here that Caloneis lewisii is a synonym of Caloneis lamella (Rumrich et al., 2000: p. 510).

Modem floristic-taxonomic investigations on the diatoms are very intensive in Europe. However, they mostly concern taxomomy of particular genera and species or much larger regions (Ector et al., 2015; Peeters \& Ector, 2017, 2018, 2019; Wojtal, 2013; Buczkó et al., 2019) than the present study. Many studies are dedicated to particular kinds of aquatic ecosystems: brackish, mineral, karst etc. (Lai et al., 2019; Lai et al., 2020; Heudrea et al., 2021) therefore it is impossible to use them in comparison of the results presented here.

\section{Conclusion}

In this study numerous species of Bacillariophyta rare in Ukraine and in the world flora were found, which evidences the significant role of protected areas in conservation of microalgae, diatoms in particular. However, all those species were present in very low numbers in the studed water ecosystems, often as single specimens in the samples, which indicates a high level of threat to their survival. Therefore, a higher status of protection can be recomended for the locations of the Yavorivsky National Park where rare species were recorded.

This research has been carried out under the scientific project No. 0120 U102586 of the National Academy of Sciences of Ukraine. The author expresses sincere gratitude to SEM operator Anastasiya Terebilenko for help in obtaining SEM micrographs; to Professor Michael Guiry, the Founder and Director of the AlgaeBase project, for the consultations on Latin names and some taxonomical questions; to all of the reviewers for attentive work with my manuscript and valuable comments for its improvement.

\section{References}

Antoniades, D., Hamilton, P. B., Douglas, M. S. V., \& Smol, J. P. (2008). Diatoms of North America: The freshwater floras of Prince Patrick, Ellef Ringnes and northern Ellesmere Islands from the Canadian Arctic Archipelago. Iconographia Diatomologica. Vol. 17. A. R. G. Gantner Verlag K. G., Rugell. 
Antoniades, D., Hamilton, P. B., Hinz, F., Douglas, M. S. V., \& Smol, J. P. (2009). Seven new species of freshwater diatoms (Bacillariophyceae) from the Canadian Arctic Archipelago. Nova Hedwigia, 88, 57-80.

Bąk, M., Witkowski, A., Zelazna-Wieczorek, J., Wojtal, A. Z., Szczepocka, E., Szulc, K., \& Szulc, B. (2012). Klucz do Oznaczania okrzemek w fitobentosie na potrzeby oceny stanu ekologicznego wod powierzchniowych w Polsce. Biblioteka Monitoringu Srodowiska, Warszawa (in Polish).

Berezovskaya, V. Y. (2019). Vidovoye raznoobraziye vodorosley rek Kievskoy vozvyshennosti (Ukraina) [Species diversity of algae of the Kiev upland rivers (Ukraine)]. Algologia, 29(1), 59-76 (in Russian)

Buczkó, K, Ács, E., Báldi, K., Pozderka, V., Braun, M., Kiss, K. T., \& Korponai, J. (2019). The first high resolution diatom record from Lake Balaton, Hungary in Central Europe. Limnetica, 38(1), 417-430.

Bukhtiyarova, L. N. (2007a). New floristic data on diatoms from Shatsky National Nature Park, Ukrainian Polissia. Materials of the III International Scientific Conference "Lake ecosystems: Biological processes, antropogenic transformation, water quality" (September 17-22, 2007). Belorusskiy Gosudarstvennyi Universitet, Minsk, Naroch. Pp. 126-127.

Bukhtiyarova, L. N. (2007b). Revision of the genus Achnanthes Bory s. lato (Bacillariophyta). 1. Genera Achnanthes Bory s. str. and Achnanthidium Kützing s. str. International Journal on Algae, 9(4), 328-341.

Bukhtiyarova, L. N. (2009). Frustule functions and functional morphology of Bacillariophyta. Algologia, 19(3), 321-331.

Bukhtiyarova, L. N. (2017a). New and rare Bacillariophyta in the algal flora of Ukraine from the Dermansko-Ostrozkyi National Park. In: International scientificpractical conference "Protection, preservation and reproduction of biodiversity in conditions of megapolis". Dysa Plus, Kyiv. Pp. 158-167.

Bukhtiyarova, L. N. (2017b). Planothidium bilensis, sp. nov. (Bacillariophyta) from a small pond in Kiev megalopolis (Ukraine). International Joumal on Algae, 19(1), 41-50.

Bukhtiyarova, L. N. (2019a). Functional morphology of the diatom frustule in systematics of Bacillariophyta. In: VI International Conference "Advances in modem Phycology". National Academy of Sciences of Ukraine, Kyiv. Pp. 24-26.

Bukhtiyarova, L. N. (2019b). The genus Eunotia Ehrenb. (Bacillariophyta) in the Cheremsky Nature Reserve, Ukrainian Polissya, and refined terminology relevant to the raphe system morphology. PhytoKeys, 128, 1-31.

Bukhtiyarova, L. N., \& Pomazkina, G. V. (2013). Bacillariophyta of Lake Baikal. Vol. 1. Genera Baikalia, Slavia, Navigeia, Placogeia, Grachevia, Goldfishia Nadiya, Cymbelgeia. Lega-Pres, Lviv.

Bukhtiyarova, L. N., \& Round, F. E. (1996). Revision of the genus Achnanthes sensu lato. Psammothidium, a new genus based on A. marginulatum. Diatom Research, 11(1), 1-30.

Bukhtiyarova, L. N., \& Stanislavskaya, E. V. (2013). Psammothidium vernadskyi sp. nov. (Bacillariophyta) from the Blue Lake, East Siberia, Russia. Algologia, 23(1), 96-107.

Burova, O. V., \& Zhezhera, M. D. (2013). Vodorosti Natsional'nogo Pryrodnogo Parku "Desniansko-Starogutskyi" [Algae of National Nature Park "Desniansko-Starogutskyi']. University Book, Sumy (in Ukrainian).

Cox, E. J. (2003). Placoneis Mereschkowsky (Bacillariophyta) revisited: Resolution of several typification and nomenclatural problems, including the generitype. Botanical Journal of the Linnean Society, 141,53-83.

Ector, L., Wetzel, C. E., Novais, M. H., \& Guillard, D. (2015). Atlas des diatomées des rivières des Pays de la Loire et de la Bretagne. DREAL Pays de la Loire, Nantes.

Ehrenberg, C. G. (1843). Verbreitung und Einfluss des Mikroskopischen Lebens in Süd- und Nord-Amerika. Abhandlungen der Königlichen Akademie der Wissenschaften zu Berlin, 1841. Pp. 291-445.

Foged, N. (1981). Diatoms in Alaska. Bibliotheca Phycologica. Vol. 53. Cramer, Vaduz.

Grunow, A. (1862). Die Österreichischen Diatomaceen nebst Anschluss einiger Neuen Arten von andern Lokalitäten und einer kritischen Uebersicht der bisher bekannten Gattungen und Arten. Verhandlungen der Kaiserlich-Königlichen Zoologisch-Botanischen Gesellschaft in Wien, 12. Pp. 315-472.

Heudrea, D., Wetzel, C. E., Van de Vijver, B., Moreaua, L., \& Ector, L. (2021). Brackish diatom species (Bacillariophyta) from rivers of Rhin-Meuse basin in France. Botany Letters, 168(1), 56-84.

Jahn, R., Kusber, W.-H., \& Cocquyt, C. (2017). Differentiating Iconella from Surirella (Bacillariophyceae): Typifying four Ehrenberg names and a preliminary checklist of the African taxa. PhytoKeys, 82, 73-112.

Konischuk, M. O. (2017). Algaflora Natsional'nogo Pryrodnogo Parka Pripiat'-Stokhid (Volynskaya obl., Ukraina) [Algal flora of the Pripiat'-Stokhid National Nature Park (Volyn region, Ukraine)]. Algologia, 27(2), 163-179 (in Russian).

Krammer, K. (2003). Cymbopleura, Delicata, Navicymbula, Gomphocymbellopsis, Afrocymbella. Diatoms of Europe. Vol. 4. A. R. G. Gantner Verlag K. G., Rugell.

Krammer, K., \& Lange-Bertalot, H. (1986). Bacillariophyceae. 1. Teil: Naviculaceae. In: Ettl, H., Gerloff, J., Heynig, H. \& Mollenhauer, D. (Eds.). Süßwasser flora von Mitteleuropa, Band 2/1. Gustav Fischer Verlag, Stuttgart, New York.
Krammer, K., \& Lange-Bertalot, H. (1987). Morphology and taxonomy of Surirella ovalis and related taxa. Diatom Research, 2(1), 77-95.

Krammer, K., \& Lange-Bertalot, H. (1991). Bacillariophyceae. 3. Teil: Centrales, Fragilariaceae, Eunotiaceae. In: Ettl, H., Gerloff, J., Heynig, H., \& Mollenhauer, D. (Eds.). Süßwasser flora von Mitteleuropa, Band 2/3. Gustav Fischer Verlag, Stuttgart, New York.

Krivenda, A. A. (2007). Konspect flory diatomovyh vodorostey ozer Shats'kogo Natsional'nogo Pryrodnogo Parku [Cheklist of diatoms in lakes of Shatskyy National Nature Park]. Chornomorski Botanical Journal, 3(1), 100-121 (in Ukrainian)

Krivenda, A. A. (2012). Novye dlya algaflory Ukrainy vidy Bacillariophyta iz vodoyemov Shatskogo Natsional'nogo Pryrodnogo Parka (Ukraina) [New for Ukraine species of Bacillariophyta from Shatskiy National Nature Park (Ukraine)]. Algologia, 22(4), 419-430 (in Russian).

Kryvosheia, O. M., \& Kapustin, D. O. (2019a). New records of diatoms for the algal flora of Ukraine from water bodies of Nyzhniosulsky National Nature Park. Ukrainian Botanical Joumal, 76(6), 554-559.

Kryvosheia, O. M., \& Kapustin, D. O. (2019b). Vidovoye raznoobrazie Bacillariophyta Natsional'nogo Pryrodnogo Parka Nyzhniosulskiy (Ukraina) [Species diversity of Bacillariophyta in the Nyzhniosulsky National Nature Park (Ukraine)]. Algologia, 29(3), 298-321 (in Russian).

Kryvosheia, O. M. (2017). Diatomovi vodorosti pepefitonu vodoym Natsional'nogo Pryrodnogo Parku 'Pyriatynsky" [Periphytic diatoms of water bodies of the National Nature Park "Pyriatynsky"]. Chomomorski Botanical Journal, 13(2), 204-214 (in Ukrainian).

Kulikovskiy, M., Genkal, S. I., \& Mikheyeva, T. M. (2013). Novye dlya Belarusi vidy diatomovyh vodorosley 4. Achanathales Silva 1962 [New diatom species found in Belarus 4. Achanathales Silva 1962]. Biological Resources, 1, 87-94 (in Russian).

Kützing, F. T. (1844). Die Kieselschaligen Bacillarien oder Diatomeen. Zu finden bei W. Köhne, Nordhausen

Lai, G. G., Padedda, B. M., Ector, L., Wetzel, C. E., Lugliè, A., \& Cantonati, M., (2020). Mediterranean karst springs: Diatom biodiversity hotspots under the pressure of hydrological fluctuation and nutrient enrichment. Plant Biosystems, $154(5), 673-684$

Lai, G. G., Padedda, B. M., Wetzel, C. E., Cantonati, M., Sechi, N., Lugliè, A., \& Ector L. (2019). Diatom assemblages from different substrates of the Casteldoria thermo-mineral spring (Northem Sardinia, Italy). Botany Letters, 166(1), 14-31.

Lange-Bertalot, H. (1999). Neue Kombinationen von Taxa aus Achnanthes Bory (sensu lato). Iconographia Diatomologica, Vol. 6. A. R. G. Gantner Verlag K. G., Rugell. Pp. 270-283.

Lange-Bertalot, H., Hofmann, G., Werum, M., \& Cantonati, M. (2017). Freshwater benthic diatoms of Central Europe: Over 800 common species used in ecological assessments. English edition with updated taxonomy and added species. Koeltz Botanical Books, Schmitten-Oberreifenberg.

Levkov, Z., Nakov, T., \& Metzeltin, D. (2006). New species and combination from the genus Sellaphora Mereschkowsky from Macedonia. Diatom Research, 21(2), 297-312.

Malakhov, Y., Kryvosheia, O., \& Tsarenko, P. (2017). Microalgae of protected lakes of Northwestern Ukraine. Polish Botanical Journal, 62(1), 61-76.

Meister, F. (1912). Die Kieselalgen der Schweiz. Beitrage zur Kryptogamenflora der Schweiz. 4(1). K. J. Wyss, Bem.

Patrick, R. M. (1945). A taxonomic and ecological study of some diatoms from the Pocono Plateau and adjacent regions. Farlowia, 2(2), 143-221.

Patrick, R. M., \& Reimer, C. W. (1966). The diatoms of the United States, exclusive of Alaska and Hawaii. Vol. 1. The Academy of Natural Sciences of Philadelphia, Philadelphia.

Peeters, V., \& Ector, L. (2017). Atlas des diatomées des cours d'eau du territoire bourguignon. Vol. 1. Centriques, Araphidées. Direction Régionale de l'Environnement, de l'Aménagement et du Logement Bourgogne-Franche-Comté, Dijon.

Peeters, V., \& Ector, L. (2018). Atlas des diatomées des cours d'eau du territoire bourguignon. Vol. 2. Monoraphidées, Brachyraphidées. Direction Régionale de l'Environnement, de l'Aménagement et du Logement Bourgogne-FrancheComté, Dijon.

Peeters, V., \& Ector, L. (2019). Atlas des diatomées des cours d'eau du territoire bourguignon. Vol. 3. Naviculacées partie 1. Adlafia, Amphipleura, Aneumastus, Anomoeoneis, Berkeleya, Biremis, Brachysira, Caloneis, Cavinula, Chamaepinnularia, Craticula, Diadesmis, Eolimna, Fallacia, Fistulifera, Geissleria, Gyrosigma, Hippodonta, Humidophila, Luticola, Mayamaea, Microcostatus, Neidiomorpha, Neidium, Nupela, Playaensis, Pseudofallacia, Sellaphora. Direction Régionale de l'Environnement, de l'Aménagement et du Logement Bourgogne-Franche-Comté, Dijon

Reichardt, E. (1999). Zur Revision der Gattung Gomphonema. Die Arten um G. affine/insigne, G. angustatum/micropus, G. acuminatum sowie Gomphonemoide Diatomeen aus dem Oberoligozän in Böhmen. Iconographia Diatomologica, Vol. 8. A. R. G. Gantner Verlag K. G., Rugell. 
Round, F. E., Crawford, R. M., \& Mann, D. G. (1990). The diatoms biology and morphology of the genera. Cambridge University Press, Cambridge.

Ruck, E. C., Nakov, T., Alverson, A. J., \& Theriot, E. C. (2016). Nomenclatural transfers associated with the phylogenetic reclassification of the Surirellales and Rhopalodiales. Notulae Algarum, 10, 1-4.

Ruck, E. C., Nakov, T., Alverson, A. J., \& Theriot, E. C. (2016). Phylogeny, ecology, morphological evolution, and reclassification of the diatom orders Surirellales and Rhopalodiales. Molecular Phylogenetics and Evolution, 103, 155-171.

Rumrich, U., Lange-Bertalot, H., \& Rumrich, M. (2000). Diatoms of the Andes From Venezuela to Patagonia/Tierra del Fuego and two additional contributions. Iconographia Diatomologica. Annotated Diatom Micrographs. Vol. 9. Phytogeography-Diversity-Taxonomy. Koeltz Scientific Books, Königstein.

Schultze, E. A. (1889). A description of the Staten Island Diatoms. Bulletin of the Torrey Botanical Club, 16, 98-104.

Schumann, J. (1867). Preussische Diatomeen. Schriften der Koniglichen Physikalisch-Okonomischen Gesellschaft zu Konigsberg, 8, 37-68.

Smith, W. (1853). A synopsis of the British Diatomaceae; with remarks on their structure, function and distribution; and instructions for collecting and presserving specimens. Vol. 1. John van Voorst, London.

Stoermer, E. F., \& Yang, J. J. (1971). Contributions to the diatom flora of the Laurentian Great Lakes. I. New and little-known species of Amphora (Bacillariophyta, Pennatibacillariophyceae). Phycologia, 10(4), 397-409.

Streett-Perrott, F. A., \& Barker, P. A. (2008). Biogenic silica: A neglected component of the coupled global continental biogeochemical cycles of carbon and silicon. Earth Surface Processes and Landforms, 33, 1436-1457.

Treguer, R., Nelson, D. M., Van Bennkom, A. J., De Master, D. J., Leynaert, A., \& Queguner, B. (1995). The silica balance in the world ocean: A re-estimate. Science, 268 (5209), 375-379.

Turland, N. J. (2019). The code decoded. A user's guide to the International code of nomenclature for algae, fungi, and plants. Advanced Books, Pensoft Publishers, Sofia.
Turland, N. J., Wiersema, J. H., Barrie, F. R., Greuter, W., Hawksworth, D. L., Herendeen, P. S., Knapp, S., Kusber, W.-H., Li, D.-Z., Marhold, K., May, T. W., McNeill, J., Monro, A. M., Prado, J., Price, M. J., \& Smith, G. F. (Eds.). (2018). International code of nomenclature for algae, fungi, and plants (Shenzhen Code) adopted by the Nineteenth International Botanical Congress Shenzhen, China, July 2017. Regnum Vegetabile, Vol. 159. Koeltz Botanical Books, Glashütten.

Van de Vijver, B., Beyens, L., \& Lange-Bertalot, H. (2004). The genus Stauroneis in the Arctic and (Sub-)Antarctic Regions. Bibliotheca Diatomologica. Vol. 51. J. Cramer in der Gebrüder Borntraeger Verlagsbuchhandlung, Stuttgart.

Van de Vijver, B., Levkov, Z., Walter, J., \& Ector, L. (2020). Observations on and typification of Navicula fontinalis Grunow (Naviculaceae, Bacillariophyta). Notulae Algarum, 143, 1-7.

Vemadskiy, V. I. (1923). Zhivoye veschestvo v khimii moray [Living matter in the chemistry of the sea]. Nauchnoe Khimiko-Tekhnicheskoe Izdatelstvo, Petrograd (in Russian).

Wasser, S. P., Kondrat'eva, N. V., Masyuk, N. P., Palamar'-Mordvinova, G. M., Vetrova, Z. I., Kordyum, E., Moshkova, N. A., Prikhotkova, L. P., Kovalenko, O. V., Stupina, V. V., Tsarenko, P., Unger, V. P., Vinogradova, O., Bukhtiyarova, L. N., \& Razumna, L. F. (1989). Vodorosli. Spravochnik [Algae. Reference Book]. Naukova Dumka, Kiev (in Russian).

Wojtal, A. Z. (2013). Species composition and distribution of diatom assemblages in spring waters from various geological formations in Southern Poland. Bibliotheca Diatomologica. Vol. 59. J. Cramer, Stuttgart.

Zakrzewski, B. S. (1934). K algoflore ozera Balkhash [The algal flora of Lake Balkhash]. Bulleten Sredne-Aziatskogo Gosudarstvennogo Universiteta, 19, 131140 (in Russian).

Zidarova, R., Kopalová, K., \& Van de Vijver, B. (2016). Ten new Bacillariophyta species from James Ross Island and the South Shetland Islands (Maritime Antarctic Region). Phytotaxa, 272(1), 37-62. 